\title{
Governance, forests and REDD+ in Latin America
}

\author{
Elena Petkova', Anne Larson', Arnoldo Contreras-Hermosilla' and Fabiano Toni ${ }^{2}$
}

\section{Key points}

- The implementation and success of REDD+ strategies, plans and projects will depend on whether REDD+ influences governance or is shaped by existing governance failures.

- As governments prepare for REDD+ implementation, they should:

- address faulty forest policies and revise development and market policies affecting forests to ensure that gains through carbon emissions reduction in one sector are not counterbalanced by losses in another;

- establish a balance between central oversight and decentralised decision-making, tenure security and transparent benefit-sharing arrangements to ensure the legitimacy of REDD+ and avoid conflicts;

- build capacity to implement and enforce the law and reduce forest crime through adequate funding levels, independence from both political and industry influence, and legal and regulatory clarity and stability.

- Achieving the necessary policy reform is a politically difficult process likely to meet resistance. However, it provides an opportunity to shift development patterns and reduce deforestation and degradation. Although civil society and external actors, including donors, can be important drivers for reform, ultimately, it will require policymakers and civil servants with initiative and vision.

\section{Introduction}

REDD+ is a potentially significant financial mechanism for shifting the incentives from deforestation and land use change to forest conservation and sustainability. Even

1 Center for International Forestry Research (CIFOR)

2 Center for Sustainable Development, University of Brasília though REDD+ is not primarily a governance instrument, it will affect or be affected by forest governance: it can either improve forest governance or be undermined by its failures. REDD+ depends on good forest governance if it is to be efficient, effective and equitable.

One of the central governance issues related to forests concerns who should be making which decisions about forests and forest resources. This includes the distribution of power and funds between central government institutions and between different levels of the state, as well as the role of communities, indigenous peoples and other citizens. These are cross-cutting issues that underpin debates over institutional arrangements and policies.

The first section of this brief examines the relationship between objectives, policies and central government entities overseeing the environment and forest conservation on the one hand, and other sectors affecting forests, on the other. In the context of REDD+, this relationship will determine whether and how to shift development patterns to address drivers of deforestation and achieve forest conservation objectives. The second section discusses forestry sector agencies specifically and their ability to ensure the rule of law. The capacity of these agencies and their ability to enforce the law are critical for REDD+. The third section addresses the distribution of powers across scales. In the context of REDD+, this is also a debate about the distribution of benefits.

\section{The relationship between forests and development}

Forest conservation and forest use depend not only on forestry sector policies but also on policies in other sectors such as agriculture, infrastructure and mining. If there is no alignment between these policies, deforestation and degradation of forests will continue despite forestry sector policies that promote conservation. 


\section{Forestry sector policy and regulatory frameworks}

During the past 2 decades, numerous countries in Latin America have adopted a variety of policies, strategies and instruments to promote forest conservation and sustainable forest use. Amongst these are requirements for management plans, forest finance instruments,

payment for environmental services and sustainable forest management strategies.

Despite progress and innovation, forestry sector policies and regulations still suffer from weaknesses. Regulation in the forestry sector is frequently excessive, covering forest resources management requirements, and prescribing when and what forest products can be harvested in what locations and how forest products should be transported and traded. In contrast, other land uses such as agriculture and ranching are not subject to such profuse regulation. Some regulations set unrealistic requirements that many forest operators cannot satisfy. In many cases, regulations affecting forests are unclear, inconsistent with each other and therefore confusing and open to various interpretations. The potential for contradictions increases as new laws and regulations are promulgated. Further, even when the necessary laws are in place, the corresponding operational regulations may be missing (see Box 1). As a result, they are difficult for forestry agencies to implement or for forest users to comply with. Regulatory overburden and confusion may also induce users and owners to convert and rezone to avoid excessive compliance standards.

\section{Policies promoting development at the expense of forests}

Traditionally, development patterns in Latin America have relied on natural resources and expansion to new land by clearing forests. This pattern reinforces, and is reinforced by, a social system that prioritises land ownership as a source of wealth and prestige ((Barry et al. 2010; Ankersen and Ruppert 2006).

As in many other parts of the world, into the late 20th century, much of Latin America's forests were seen as unproductive lands available for the taking. For example, a 1977 report by the Inter-American Development Bank (IADB) referred to Nicaragua's forests as 'idle resources' that could be put to productive use through conversion to agriculture or pasture (IADB 1977). This perspective led to policies and market incentives that continue to this day to promote deforestation and degradation.

Macroeconomic policies have had and still have negative impacts on forests. Trade liberalisation and structural adjustment played an important role in stimulating deforestation across Latin America. Global and domestic markets for food, fibre and biofuel create competition with forests for land. Perverse fiscal policies, including low fees for timber concessions and subsidies for forest plantations, especially for agriculture and ranching, have caused largescale conversion and deforestation. Lending policies to cattle ranching and associated businesses have complemented subsidies to cause massive deforestation.

\section{Box 1. Examples of regulatory weaknesses}

Unrealistic regulations: The Honduran government requires communities to prepare forest management plans. Most communities simply do not have the technical capability to design and implement the required plans or the capacity to hire a forest professional who can produce such plans. Even if plans are developed, it takes 2 years to obtain government approval (Del Gatto 2002).

Regulatory overburden: Mexico has more than 100 environmental laws with discrepancies and conflicts amongst them (Enriquez et al. 2009).

Missing regulations: The Forest Management Act of Suriname was approved in 1992, but the implementing regulations were issued 8 years later, creating great uncertainty about how the law should be put into practice in the interim (Playfair 2007). 


\section{Box 2. Examples of impacts on forests by non-forestry sector policies and projects}

- Trade liberalisation and global demand stimulated dramatic increases in investments in agriculture and accelerated deforestation in lowland Bolivia (Hecht 2005).

- Subsidies for timber plantations, established with the intention of reducing pressure on natural forests, made forest plantations highly profitable in Chile and Brazil and increased pressure on forests.

- An audit by Brazil's Federal Audit Court ruled that BNDES, Brazil's national development bank, had contributed to Amazon deforestation by lending billions of dollars to commercial meatpackers, thus driving expansion of cattle ranching across the world's largest rainforest (Butler 2010b).

- Biofuel blending targets in the EU, United States, Brazil and others may have unpredictable impacts on forests as they are likely to require increasing amounts of land (Schoneveld 2010).

- In Brazil, each kilometre of new roads leads to between 400 and 2000 ha of deforestation (Amor Conde et al. 2007).

Subsidies and perverse incentives almost always benefit relatively small but powerful groups. In the past, these groups have opposed any revision of the status quo; they are likely to continue to do so in the future.

\section{Development of non-forestry sectors such as} agriculture, infrastructure, oil and gas is a main cause of deforestation in Latin America. Thus, cattle ranching, made attractive by a combination of factors such as land prices and tenure policies, caused an estimated $65-70 \%$ of all the deforestation in the Brazilian Amazon between 2000 and 2005 (Butler 2010a). Transport infrastructure, including for mining and oil extraction, opens up new forest areas previously protected from loggers and other operators by their inaccessibility. New roads increase accessibility and the financial profitability of converting forested lands to agriculture (Hecht 1985, Repetto and Gillis 1988, Binswanger 1989, Contreras-Hermosilla 2000). Furthermore, weak implementation of environmental safeguards in such projects by governments or international financing institutions such as the World Bank and the International Finance Corporation (IFC) has also led to deforestation (Dourojeanni et al. 2009).

\section{Forests, development and REDD+}

Latin American countries have undertaken a variety of forest policy reforms. For implementation of REDD+ strategies and plans to be successful, it is necessary to remove faulty policy frameworks and ensure alignment of policies across sectors-both requiring drastic policy reform.

Policies in the forestry sector need to make forest conservation and use attractive and possible. To achieve this, they need to be clear, realistic and complete. Incentives in the forestry and other sectors should give the right signals to promote conservation rather than deforestation and degradation.

An enhanced role of forests in climate change mitigation requires an integral approach to development and markets affecting forests, to ensure that gains in carbon emissions reductions through policies in one sector are not counterbalanced by losses through incentives for deforestation and degradation in another. Only then should countries be rewarded for performance.

This is a politically difficult process that is likely to meet significant resistance. Reformers must understand the political landscape and design diverse strategies to thwart or at least deflect resistance by the key groups who will be affected negatively. These strategies should ensure that reforms are politically desirable, feasible and credible. Although civil society and external actors, including donors, can be important drivers for good governance, its design and practice will require policymakers and civil servants with initiative and vision (DFID 2005). Reforms will make it possible to realise the 
opportunity to shift development patterns and reduce deforestation and degradation.

\section{Forestry sector agencies and the rule of law}

The capacity of forestry sector agencies influences their relationship with agencies overseeing other sectors and affects their ability to implement forestry sector policies and enforce the law.

\section{Capacity of forestry sector agencies}

The recent trend to relocate forest administrations to environment ministries or autonomous units has been accompanied by a shift in mandates to include conservation and sustainable forest management, usually as part of broader reforms. Some countries completely restructured their forestry services in the 1990s (e.g. Bolivia, Guatemala, Mexico, Peru). Others have done so more recently (e.g. Honduras).

The new arrangements and the greater attention to conservation have led to clear improvements in forestry statistics and information. However, little has changed in the overall emphasis on timber. Enforcement capacity remains weak. An ITTO report (2006) concludes, 'the designated forest authorities appear to lack the resources to adequately implement and enforce their forest laws'. Case studies of the effectiveness of the verification system in Brazil, Costa Rica, Honduras and Nicaragua assessed level of funding, independence and regulatory coherence and clarity. Political mandates and the transparency of the system were also discussed in some of the case studies (Brown et al. 2008). The case studies suggest the following.

- Most agencies are under-funded: insufficient funding limits the agencies' ability to verify and enforce.

- Political dependence in some cases opens these agencies to pressures and exposes them to risks at times of political change.

- Dependence on logging industries in Costa Rica and Brazil exposes staff in the field to influence by vested interests and corruption.

- Legislative uncertainty, confusion and gaps in Nicaragua limit agencies' ability to enforce.

\section{Enforcement and the rule of law}

Forestry agencies' capacity and independence are critical to their ability to control illegal logging and ensure the rule of law. Illegal logging contributes to deforestation and leads to losses of government revenue. Illegal logging estimates vary widely for different reasons, such as data scarcity or legality definitions. A recent study by Chatham House reports a decline but even so, 2008 estimates of illegal timber are close to $40 \%$ of total timber production in Brazil (Lawson et al. 2010). In Ecuador, illegal logging was estimated at 70\%, in Peru at 80\% in 2004 (WWF 2004), and in 2010 in Bolivia it was 70\% (Bolivia Forestal 2010).

Illegal logging is closely connected to corruption. Corruption levels vary widely across Latin American countries; Chile and Uruguay are effectively controlling corruption, whilst the other Latin American countries range across the spectrum according to the Worldwide Governance Indicators, with most falling below the global average according to Transparency International rankings (Kaufmann et al. 2009, TI 2010).

It is widely accepted that reducing forest crime, including corruption, illegal logging and trade, requires transparency of the government system and independence of its component parts. However, the case studies cited above suggest that some forestry agencies, or at least their verification branches, are either dependent on the industry or subject to political influences. Limited funding indicates the lack of political will to address illegal logging and corruption in forests.

\section{Forestry agencies, the rule of law and REDD+}

Corruption, illegal logging and associated elite capture, and particularly the vested interests behind them, are key obstacles to reform (DFID 2005). The potential of REDD+ initiatives will depend on governance reform. That is, illegal logging and corruption can indirectly undermine REDD+ by undermining reform efforts designed to support its objectives.

Illegal logging and corruption also pose direct risks for REDD+ in 2 ways. First, REDD+ is associated with potentially large sums of money. Corrupt practices in the transfers and payments of REDD+ funds will divert 
parts of these funds, thus undermining the ability of governments to effectively curb deforestation and forest degradation. Second, the ability of the government to curb illegal logging will determine whether reductions through REDD+ initiatives are offset by increases caused by illegal activities.

Adequate funding levels, independence from both political and industry influence, and legal and regulatory certainty and comprehensiveness are critical to forestry agencies' capacity and rule of law, both of which are instrumental to REDD+.

\section{Distribution of power across scales and between groups}

The distribution of power across different levels of government and between different stakeholder groups will affect how REDD+ will be managed, who influences or makes decisions, who will be involved in implementation and, ultimately, who will benefit. Disputes and shifts in power are associated with the relationship between central and subnational governments as well as that between the government and communities and citizens.

\section{Central and subnational governments}

The extent to which decisions about forests are centralised or decentralised cannot be separated from the overall degree of political decentralisation in a country. Latin American countries have made significant progress in political decentralisation. Nevertheless, some authors (e.g. Mitchell 2006) are pessimistic, on the grounds that 'national parties and political bureaucracies may try strenuously to maintain centralised control'. Decentralisation in the forestry and environment sectors in particular has been even more recent and tentative.

Decentralisation has both advanced and receded, depending on the specific negotiation at hand, often in the same country at the same time. A study of forestry decentralisation in Bolivia, Brazil, Guatemala, Honduras and Nicaragua found that where powers were being decentralised at all, this was being conducted on a case-by-case basis by contract-a strategy that runs the risk of maintaining decision-making at the central level (Larson et al. 2007). Frequently, decentralisation of forest policies has been driven by demands from subnational governments and its outcomes have depended on the ability and interests of these governments to reduce deforestation. However, the availability of considerable REDD+ financial resources might encourage central governments to devise a fully funded decentralisation programme or, reversely, strengthen centralisation trends.

\section{Box 3. Decentralisation in forestry in Brazil}

The Brazilian state of Amazonas assumed responsibility for forest management and promptly simplified the bureaucratic process for issuing permits. It legalised small and medium-scale rural operators and increased their incomes, created new environmental and forestry agencies and recruited staff (Toni 2006). The state government of Mato Grosso prioritised the creation of a state-wide land registry system and the licensing of agricultural activities.

\section{The state, communities and citizens}

The debate about the distribution of power between the state and its citizens-either as individuals or as communities_-focuses on 2 issues: the transfer of rights over forested land and citizen participation.

Tenure rights. Many Latin American governments are reforming land tenure policies in favour of indigenous communities and local people. However, the gap between formal legal rights and reality is often wide (Cotula and Mayers 2009). Even when local tenure rights have been granted on paper, the process of implementing them in practice has been fraught with competition by other interest groups (Larson et al. 2010). Further, rights frequently come with limits. In Guyana, for example, Amerindians' rights were regulated in 2006, but significant restrictions on land use persist.

Policies regarding forestland in Latin America have led to conflict primarily in 2 situations: (1) when the central government assigns resource concessions on lands claimed by resident traditional and indigenous communities, or (2) when it creates protected areas 
or otherwise restricts use rights to land that provides livelihoods to local communities.

Citizen participation. Citizen participation has been promoted by collective action and the media. It is now framed by general laws such as those related to access to information, or specific provisions for free, prior and informed consent. Today, many Latin American countries have Constitutional provisions and laws to promote participation (Saule et al. 2002); as of 2008, 11 countries had passed freedom of information laws, and others, such as Brazil, had stated a commitment to do so (Mendel 2008). Citizen participation in forestry in particular has also been addressed through land tenure policies granting new rights to forest-based communities, the creation of forest user groups and various types of co-management arrangements, as well as the promotion of community forestry. However, these have not always led to effective participation in practice.

\section{Distribution of power and REDD+}

Existing REDD+ proposals include elements that call for both recentralisation and decentralisation. On the one hand, to be most effective, REDD+ needs central organisation and oversight. This would permit greater attention to policy reform and to some of the most important indirect or larger-scale drivers of deforestation and degradation. It would also permit generation of national-scale data and control of leakage in the country. In theory, these functions would benefit from economies of scale, coordination and standardisation (Phelps et al. 2010).

However, central oversight may reinforce bureaucratic tendencies to centralise decisions of all kinds and promote closed-door decision-making, which in turn allows undue influence by vested interests. If REDD+ resources are significant, competition for such interests is likely to be intense and may also strengthen centralisation tendencies.

On the other hand, REDD+ may promote decentralisation. It could change the structure of incentives for subnational policymakers, particularly governors in federal states such as Brazil or Mexico, encouraging them to pursue further decentralisation, control deforestation and restore degraded forests in order to keep receiving REDD+ funds. A key advantage of a nested approach to REDD+ would be in ensuring that forest-dependent communities have the possibility of being engaged directly in forest carbon transactions, and thereby reduce their dependency on a centralised system. REDD+ therefore needs a balance between central organisation and oversight and decentralised decision-making and involvement.

REDD+ will require large areas to achieve effective $\mathrm{CO}_{2}$ reductions. REDD+ could lead to competition for the rights to forest areas by powerful actors (see Cotula et al. 2008) and undermine local people's rights and livelihoods. An assessment of the lessons learned in implementing the initial steps of REDD+ country initiatives reveals that about half the countries analysed face serious issues related to land tenure and uncertainty affecting user rights - a key barrier to the effective implementation of forest carbon programmes (Harvey et al. 2010). The risks are therefore dual —on the one hand, REDD+ may undermine local tenure rights, and on the other hand, it may be undermined by lack of clarity and conflict over rights

Transparent decision-making involving communities, indigenous peoples and citizens is likely to help address some of these conflicts. This is particularly important with regard to new rules for forest use both to avoid hardship and to promote local support or 'buy in' for REDD+.

REDD+ could influence these processes in many ways. However, its legality and legitimacy are likely to depend on a balance between central oversight and decentralised decision-making, clear tenure and benefit-sharing arrangements and transparency.

\section{Conclusions}

The ability of Latin American countries to enhance the role of their rich forest resources in mitigating climate change by reducing deforestation and forest degradation is closely linked with their commitment to governance reform. Therefore, REDD+ is not just a narrow strategy, plan or series of projects. The implementation and success of REDD+ depend on whether it shapes governance or is shaped by existing governance failures.

REDD+ is being designed as a performance-based mechanism. Good performance and effective carbon emissions reductions at the national level require the removal of faulty policy frameworks, alignment of policies across sectors, capacity and independence of forestry 
agencies, balanced distribution of power across scales and between groups, and stakeholder engagement in decisions and benefits.

Most of the existing failures are linked to vested interests, established development patterns and problematic relationships between agencies overseeing different spheres and sectors. Addressing these issues will negatively affect powerful groups and will shift relationships, powers and benefits. Nevertheless, it will also open new paths of development and opportunities going beyond REDD+.

\section{References}

Amor-Conde, D., Burgues, I., Fleck, L.C., Monterola, C. and Reid, J. 2007 Análisis ambiental y económico de proyectos carreteros en la Selva Maya. Un estudio regional. Serie Técnica 10, Conservation Strategy Fund, California, USA.

Ankersen, T. and Ruppert, T. 2006 Tierra y libertad, the social function doctrine and land reform in Latin America. Tulane Environmental Law Journal, 19.

Barry, D., Larson, A.M. and Colfer, C.J.P. 2010 Forest tenure reform: An orphan with only uncles. In: Larson, A.M., Barry, D., Dahal G.R. and Colfer, C.J.P. (eds). Forests for people: community rights and forest tenure reform. Earthscan, London.

Binswanger, H. 1989 Brazilian policies that encourage deforestation. Working Paper No. 16, Environment Department. World Bank, Washington, DC.

Bolivia Forestal 2010 El deber: CFB alerta por reduccion del concesiones forestales. Camara Forestal de Bolivia.

Brown, D., Schreckenberg, K., Bird, N., Cerutti, P., Del Gatto, F., Diaw, C., Fomete, T., Luttrell, C., Navarro, G. and Oberndorf, R. 2008 Legal timber: verification and governance in the forest sector. Overseas Development Institute, London.

Butler, R. 2010a Human threats to rainforests: cattle pastures. http://rainforests.mongabay.com/0812.htm (November 2010).

Butler, R. 2010b Brazil's national development bank found guilty of driving Amazon deforestation. 25 October. http://news.mongabay.com/2010/1025-bndes_ amazon.html (November 2010).

Contreras-Hermosilla, A. 2000 The underlying causes of forest decline. CIFOR Occasional Paper 30. CIFOR, Bogor, Indonesia.
Cotula, L. and Mayers, J. 2009 Tenure in REDD: start point or afterthought? Natural Resources Issues No. 15. International Institute for Environment and Development, London.

Cotula, L., Dyer, N. and Vermeulen, S. 2008 Fuelling exclusion? The biofuels boom and poor people's access to land. International Institute for Education and Development, London.

Del Gatto, F. 2002 La produccion forestal no controlada en Honduras. ¿Qué es? ¿Cuánto cuesta? Unas respuestas preliminares. Consultant Report. Tegucigalpa, Honduras.

Department for International Development (DFID) 2005 Using drivers of change to improve aid effectiveness. DFID Practice Paper. DFID, London.

Dourojeanni, M., Bandariarán, A. and Dourojeanni, D. 2009 Amazonía Peruana en 2021. Pronaturaleza, Peru.

Enriquez, S., Landa R., Madrid, S., Meli, P., Tolisano, J. and Yeager, C. 2009 Assessment of tropical forest and biodiversity conservation in Mexico. Report prepared for the United States Agency for International Development. USAID, Washington, DC.

Harvey C.A., Zerbock O., Papageorgiou S. and Parra A. 2010 What is needed to make REDD+ work on the ground? Lessons learned from pilot forest carbon initiatives. Conservation International, Arlington, VA, USA.

Hecht, S. 1985 Environment, development and politics: capital accumulation and the livestock sector in eastern Amazonia. World Development 13(6): 663-684.

Hecht, S. 2005 Soybeans, development and conservation on the Amazon frontier. Development and Change 36(2): 375-404.

Inter-American Development Bank (IADB) 1977 El subsector pecuario en Centroamerica. Division de Estudios Generales, Departamento de Desarrollo Económico y Social. IADB, Managua.

International Tropical Timber Organization (ITTO) 2006 Status of tropical forest management 2005. ITTO Technical Series No. 24. ITTO, Yokohama, Japan.

Kaufmann, D., Kraay, A. and Mastruzzi, M. 2009 Governance matters VIII. Policy Research Working Paper 4978. Development Research Group, World Bank, Washington, DC.

Larson, A., Pacheco, P., Toni, F. and Vallejo, M. 2007 Trends in Latin American forestry decentralisations: legal frameworks, municipal governments and forest- 
dependent groups. International Forestry Review 9(3): 734-747.

Larson, A., Barry, D., Dahal, G.R. and Colfer, C.J.P. (eds.)

2010 Forests for people: community rights and forest tenure reform. Earthscan, London.

Lawson, S. and MacFaul, L. 2010 Illegal logging and related trade: indicators of the global response. Chatham House, London.

Mendel, T. 2009 The right to information in Latin America: a comparative legal survey. United Nations Educational, Scientific and Cultural Organization, Quito, Ecuador. http://unesdoc.unesco.org/ images/0018/001832/183273e.pdf (August 2010).

Mitchell, C. 2006 New studies of political decentralization in Latin America. Latin American Research Review 41(3): 175-184.

Phelps, J., Webb, E.L. and Agrawal, A. 2010 Does REDD+ threaten to recentralize forest governance? Science 328: 312-313.

Playfair, M. 2007 Law compliance, and prevention and control of illegal logging activities in the forest sector of Suriname. World Bank, Washington, DC.

Repetto, R. and Gillis, M. (eds) 1988 Public policies and the misuse of forest resources. A World Resources Institute Book. Cambridge University Press, Cambridge, UK.
Saule, N., Velasco, A.M. and Arashiro, Z. 2002 Legal frameworks for citizen participation: Latin America regional report. LogoLink, University of Sussex. http:// www.ids.ac.uk/logolink/resources/legalframeregional. htm (August 2010).

Schoneveld, G. [in press] Potential land use competition from biofuel expansion in developing countries; CIFOR, Bogor, Indonesia.

Seneca Creek Associates and Wood Resources International, 2004 Illegal logging and global wood markets: the competitive impacts on the US wood products industry. Maryland and Washington, USA. www.llegallogging.info/uploads/afandpa.pdf (July 2010).

Toni, F. 2006 Gestão florestal na Amazônia Brasileira: avanços e obstáculos em um sistema federalista. CIFOR, Bogor, Indonesia.

Transparency International (TI). 2010 Corruption perceptions index 2010 results. http://www. transparency.org/policy_research/surveys_indices/ cpi/2010/results (November 2010).

WWF 2004 The scale of illegal logging. http://www.wwf.de/ fileadmin/fm-wwf/pdf-alt/waelder/Scale_of_illegal_ logging_around_the_world.pdf (November 2010).

This summary was drawn from three papers: 1) People, governance and forests: The stumbling blocks in forest governance reform in Latin America; 2) Decentralisation and REDD+ in Brazil; 3) Synergies and opportunities: An introduction to forest governance, people and REDD+ in Latin America, prepared for the 'Workshop on forest governance, decentralisation and REDD+ in Latin America and the Caribbean', Oaxaca, Mexico, 31 August - 3 September 2010. The workshop was a country-led initiative in support of the United Nations Forum on Forests (http://www.cifor.cgiar.org/Events/Oaxacalist/introduction.htm). The full papers will be published in a special issue of Forests, an open access journal of forestry and forest ecology: http://www.mdpi.com/journal/forests.

\section{Center for International Forestry Research}

CIFOR advances human wellbeing, environmental conservation and equity by conducting research to inform policies and practices that affect forests in developing countries. CIFOR is one of 15 centres within the Consultative Group on International Agricultural Research (CGIAR). CIFOR's headquarters are in Bogor, Indonesia. It also has offices in Asia, Africa and South America.

Swiss Confederation

Federal office for the Environment FOEN 